\title{
Adrenergic Agonist and Antagonist Action in Airways of Patients with Bronchial Asthma
}

\author{
Hilmi Islami ${ }^{1 *}$, Shaip Krasniqi ${ }^{2}$, Bedri Abdullahu ${ }^{3}$ and Ibrahim Ibrahimi ${ }^{4}$ \\ ${ }^{1}$ Department of Pharmacology, Faculty of Medicine, University of Prishtina, Clinical Centre N.N. 10000, Prishtina, Kosova \\ ${ }^{2}$ Department of Pharmacology, Faculty of Medicine, University of Prishtina, Clinical Centre N.N. 10000, Prishtina, Kosova \\ ${ }^{3}$ Department of Pharmacy, Faculty of Medicine, University of Prishtina, Clinical Centre N.N. 10000, Prishtina, Kosova \\ ${ }^{4}$ Department of Pharmacology, Faculty of Medicine, University of Tetove, Ilindenska N.N. Tetove, Macedonia
}

\begin{abstract}
In this study, the effect of dopamine as agonist dopaminergic receptor and alpha and beta adrenergic receptor was studied both in vivo. The effect of tolazoline as an antagonist of alpha-2 adrenergic receptor was also studied in patients with bronchial asthma and persons with increased bronchial reactibility. Parameters of the lung function are determined by body plethysmography. Raw and ITGV were registered and SRaw was calculated as well. Aerosolization is done with standard aerosolizing machines - Asema. Results gained in vivo shows that stimulation of alpha adrenergic receptor with dopamine $(4 \mu \mathrm{g}$ and $300 \mu \mathrm{g})$ causes significant contraction $(p>0.1)$ of the smooth bronchial musculature. Whereas, blockage of alpha- 2 adrenergic receptor with tolazoline ( $20 \mathrm{mg}$ by inhalator ways) does not change the bronchimotor tonus significantly $(p>0.1)$ when compared to the stimulation of beta- 2 adrenergic receptor with hexoprenaline ( $2 \mathrm{inh} . \times 0.2 \mathrm{mg}$ ) and blocker of cholinergic receptor - ipratropium ( $2 \mathrm{inh} . \times 1 \mathrm{mg})$. Reaction of the smooth musculature to dopamine suggests that this substance may cause constriction through alpha adrenergic receptors. Reaction may also be intermediated in indirect ways through dopaminergic receptor of the cholinergic transmission, with intracellular inhibition of the creation of cAMP.
\end{abstract}

Keywords: Respiratory System; Dopamine; Tolazoline; Hexoprenaline; Ipratropium

\section{Introduction}

Dopamine has many functions which, as of yet, are not fully clarified. Although dopamine in high doses stimulates alpha and beta adrenergic receptor, physiologic endogen actions of dopamine are intermediated primarily by dopaminergic receptors. In the central nervous system, the role of the neurotransmitter is attributed to dopamine and noradrenalin, whereas there is little knowledge of adrenaline as a neurotransmitter [1]. $\mathrm{D}_{2}$, the preganglionic receptor of dopamine acts as autoreceptor which reduces the quantity of noradrenalin released by sympathetic nerve endings [2,3]. Inhibition of the creation of cAMP through $\mathrm{D}_{2}$ dopaminergic receptor is directly proportional with the dopaminergic control of the cholinergic transmission [4]. Some subgroups of dopaminergic receptor exist, from which $\mathrm{D}_{1}$ dopaminergic receptor are studied mostly. These subgroups are placed in postganglionar connections associated with the adenylate cyclase system. $\mathrm{D}_{2}$ dopaminergic receptor are mainly placed in presynaptic nerve endings and their stimulation does not cause the activation of adenylate cyclase, but it leads towards its inhibition which is manifested by the reduction of cAMP production [5]. In the normal regulation of the tonus of smooth muscles there exists a light, but constant, bronchoconstrictor tonus that is maintained through the intermediation of cholinergic impulses [6]. The role of the adrenergic nervous system in normal people and in patients with bronchial asthma and obstructive bronchitis has had little research done. Strengthened bronchial reactibility of the airways of asthmatics is due to imbalance, which derives from the decreased beta-adrenergic function (which results in increase of cholinergic response) and alpha-adrenergic response against different stimulators $[7,8]$. Although, the mechanism of hyperactivity of the adrenergic system is not yet entirely known [9-11] some authors have found that the resistance of the airways in asthmatics is increased following the application of alpha adrenergic agonist. This was not noticed in healthy people. Lately, experiments conducted in vivo prove that clonidine intermediates an inhibitor control of the existing vagal activity. However, these results are not verified by other researchers [12]. Thomson et al. [13] has proved that in the group of asthmatics, agonist of alpha-1 adrenergic receptor, inhaled phenilefrine does not affect the airway resistance. Many researchers point out that in a group of selected asthmatic patient, without any other medications, administration of alpha-adrenergic antagonist leads towards an improvement of the airway function [14,15]. Alphaadrenergic antagonists (e.g. indoramin) cause the bronchodialation due to the blocking of alpha-adrenergic receptors and can be useful therapeutics for certain asthmatic populations [16]. It remains unclear whether these results are caused by the blockage of stimulation of the mastocyte's alpha-adrenergic receptor, or the airways smooth muscles [17]. We have undergone this study in order to evaluate the effect the stimulation and the blockage of alpha adrenergic receptor with dopamine and tolazoline has on the response of the airways smooth musculature in persons with bronchial asthma.

\section{Materials and Methods}

Research was conducted in vivo. Examinations were conducted on 18 patients who have suffered from bronchial asthma and obstructive chronic bronchitis. Patients were selected based on anamnestic data, clinical research and functional research of the respiratory system. Some characteristics of the study group and their pulmonary function are provided in the (Table 1 and Table 2). Patients were informed regarding the aim of examination at least 48 hours prior to the beginning of the research. Patients with the disease were not administered any bronchodilatory drugs, corticosteroids and anti-inflammatory, anticholinergic and similar non-corticosteroid substances. Lung function

*Corresponding author: Hilmi Islami, MD PhD, Institute of Clinical Pharmacology and Toxicology, Faculty of Medicine, Prishtina University, "Mother Theresa "str Rrethi i spitaleve pn. 10000 Prishtina, Republic of Kosova, Tel: 0037745437 415; Fax. 0038138551 001; E-mail: islamihilmi@hotmail.com

Received June 17, 2011; Accepted November 08, 2011; Published November 10,2011

Citation: Islami H, Krasniqi S, Abdullahu B, Ibrahimi I (2011) Adrenergic Agonist and Antagonist Action in Airways of Patients with Bronchial Asthma. J Pulmonar Respirat Med 1:104. doi:10.4172/2161-105X.1000104

Copyright: ( 2011 Islami H, et al. This is an open-access article distributed under the terms of the Creative Commons Attribution License, which permits unrestricted use, distribution, and reproduction in any medium, provided the original author and source are credited. 
was determined in the silence condition. This determination is constituted from the measurement of the slowed vital capacity (VC), forced expiratory volume in 1 minute $\left(\mathrm{FEV}_{1}\right)$ with the use of the Godardt Company pneumotest, and afterwards by metering of the resistance of the air flow in lung (Raw) and intratoracal volume of gas (ITGV) by the body plethysmography. From the gained Raw and ITGV results, specific resistance (SRaw) was calculated.

\section{SRaw $=$ Raw $\times$ ITGV}

\section{Consort Flow Diagram}

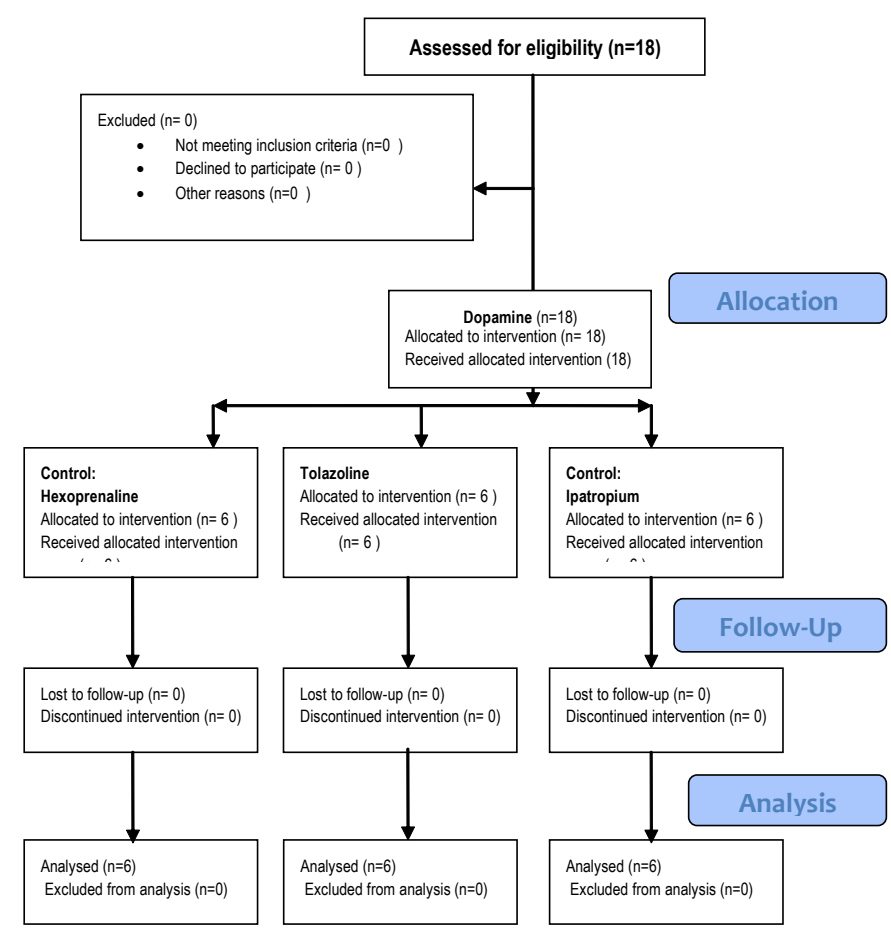

Measurement with body plethysmography

On the first day, following the assessment of initial values for permeability of airways, a solution of aerosolized dopamine was administered through an inhalator ASEMA in a dose of $(4 / \mu \mathrm{g} / \mathrm{kg}$ and $300 / \mu \mathrm{g})$. Immediately following the inhalation, values of Raw and ITGV were measured. These measurements were repeated after 5, 15, 30, 60 and 120 minutes. Afterwards, patients were given hexoprenaline ( 2 inh. $x 0.2 \mathrm{mg}$ ) and values were measured.

On the second day, following the respective parameters of the lung function, tolazoline was administered as an aerosol $(20 \mathrm{mg} / 2 \mathrm{ml} / 5 \mathrm{~min})$ through an inhalator Asema with an aerosolization rate of $0.5 \mathrm{ml}$ per one minute. Immediately following the inhalation, Raw and ITGV, arterial pressure, pulse, and measurements were measured and measurement was repeated after 5, 15, 30, 60, 120 and 140 minutes after inhalation.

On the third day, ipratropium was administered as an aerosol to the same patient ( 2 inh $\mathrm{x} 1 \mathrm{mg}$ ) and immediately following the inhalation Raw and ITGV, blood pressure, pulse, and the same parameters were measured after 5, 15, 30, 60, 120 and 140 minutes after first inhalation (Figure 1a,1b).

Results were processed with statistical computer software GraphPad InStat III. Significant changes were calculated with t-test.

\section{Results}

In vivo studies of the patients with bronchial asthma and with chronic obstructive bronchitis, results showed that stimulation of alpha adrenergic receptor with dopamine $(4 \mu \mathrm{g}$ and $300 \mu \mathrm{g})$ causes significant contraction of the smooth tracheal musculature $(\mathrm{p}<0.01)$. Two hours following the inhalation of dopamine, hexoprenaline was applied (stimulator of beta ${ }_{-2}$ adrenergic receptor) which caused a significant decrease in the airway resistance $(\mathrm{p}<0.01)$ (Figure 2 and Figure 3 ). Whereas, blockage of alpha-2 adrenergic receptor with tolazoline (20 mg administered with inhalator) does not change in a significant manner $(p>0.1)$ the bronchomotor tonus in comparison to ipratropium bromide ( 2 inh. x $1 \mathrm{mg}$ ) (Figure 4).

\section{Discussion}

Regulation of the airways tonus and pharmacology of bronchoconstrictor phenomenon are not fully understood. A huge number of studies of how the mechanism of airway function is regulated indicate the considerable role of the relaxing influence of the beta adrenergic receptor, constrictor actions of alpha adrenergic receptor and interaction of neurohumoral factors in this regulation. Existance of these receptors and their role in healthy and people ill from bronchial asthma and chronic obstructive bronchitis is not fully clarified. In the mechanism of lung obstructive diseases and bronchial asthma modulator substances, released after the inflammatory processes, have an important role, as do other substances released following the process of de-granulation of mastocyte [18].

The fact that tolazoline caused no reaction of alpha adrenergic receptors in the permeability of airways with reversible changes of the lung function, is in accordance with the results of Thomson et al. [13] and Barnes et al. [9]. These authors found no response to prazosin, a very powerful selective antagonist of alpha-1 adrenergic receptor. Contrary to our results, some other researchers did find alphaadrenergic response in airways of patients with bronchial asthma. We have to mention here that Lindgren et al. [19] have demonstrated the inhibition of bronchoconstriction with clonidine, an alfa-2 adrenergic blocker. Within the group of studied patients in this work, dopamine's significant response after two hours of application was demonstrated on the resistance of airways. It is deemed that the constriction of the smooth bronchial musculature to dopamine is caused in indirect ways by dopaminergic control of the cholinergic transmission with the inhibition of the cAMP creation. This raises a question: why do the same receptors react to agonist substances while they do not react on antagonist substances! This suggests that a relationship exists between alpha and beta adrenergic receptors that might be an important mechanism in explaining the responses of patients with increased bronchial reactibility. Similar results were obtained by author Walden et al. [20] which showed that the blockage of alpha adrenergic receptors through the application of phentolamine had no significant impact to the reaction of the smooth musculature of airways to histamine. Although in some patients with asthma there are improvements of lung functional tests $\left(\mathrm{FEV}_{1}\right)$, but these improvements are not significant [20]. The role of the phentolamine in the airways tonus should not

\begin{tabular}{|c|c|c|c|}
\hline $\mathrm{n}$ & Age $(\mathrm{v})$ & Height $(\mathrm{cm})$ & Mass $(\mathrm{kg})$ \\
\hline 18 & $28.8 \pm 3.86$ & $171.4 \pm 3.54$ & $67.0 \pm 0.4$ \\
\hline
\end{tabular}

Table 1: Characteristics of the research patient study group.

\begin{tabular}{|c|c|c|c|c|}
\hline $\mathrm{n}$ & VC (\%) & FEV-1 (\%) & Raw (kPa L/s) & ITGV (L) \\
\hline 18 & $93.82 \pm 2.04$ & $69.46 \pm 8.04$ & $0.36 \pm 0.03$ & $4.08 \pm 0.14$ \\
\hline
\end{tabular}

Table 2: Pulmonary function in the research patient study group. 


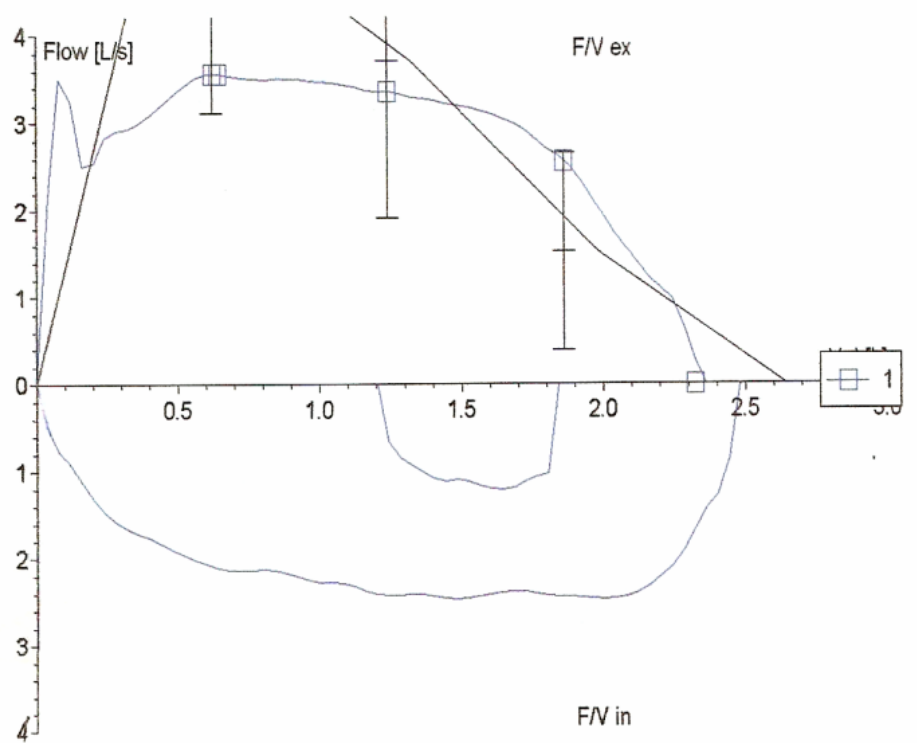

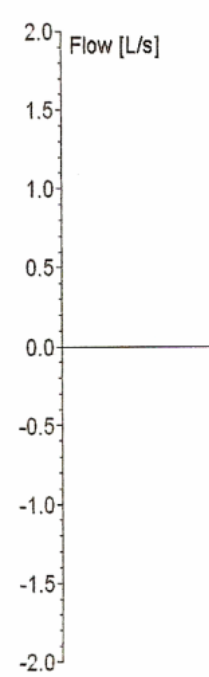

$-2.0$

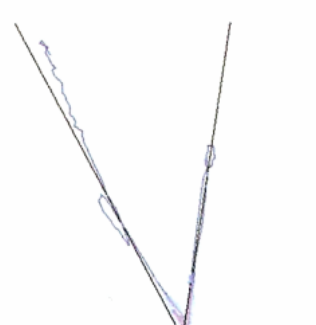

Mouth pressure $[\mathrm{KPa}]$

Figure 1: Measurement with Body plethysmography. a. Measurement of parameters of the gas volume in the sternum (ITGV); registration of curve flux-volume (inspiratory flux and expiratory flux - L/min); b. Resistance of airways (Raw - L/sec.) expressed in $\mathrm{kPa}$.

be totally eliminated. As author Giussani et al. has reported, systemic administration of phentolamine causes the increase of the incidence, rate and amplitude of respiratory movements of sheep's fetus in utero during hypoxia. This proves the connection of phentolamine in central mechanisms of breathing [21]. Studies show that fentolamine applied inhalational and intravenously in patients with bronchial asthma does not reduce the specific resistance (SRaw) of respiratory tracts [22].

The question remains as to whether constriction of smooth respiratory musculature is caused by two sub-types of alpha adrenergic receptors (alpha-1 and alpha-2) since that adrenergic receptor reacts in some agonist substances and do not react on alpha adrenergic substances! Regarding this, there are neither earlier reports by which to prove two sub-types of alpha adrenergic receptors in the airways smooth musculature nor are there reports on the effects of clonidine in the receptors of smooth musculature [23]. Previous researchers have shown that there are no alpha-2 adrenergic receptors in the respiratory epithelia surface [18]. Recently, experiments conducted in vivo show that clonidine intermediates an inhibitory control over the activity of vagal excitation [24]. Inhibitory effect of the clonidine in bronchoconstriction might be induced with straight bronchodilation, through inhibition of the vagal reflex, or with the inhibition of the release of histamine, inhibition caused by an antigen [19].

Thomson et al. has confirmed that asthmatics treated with the inhalation of phenylephrine (agonist of alpha-adrenergic receptor) did not show a significant change in the airways resistance [13].

Results of this research, like that of other authors, indicates the pharmacologic relevance of $\beta-2$ agonists (hexoprenaline) and anti-cholinergic substances (ipratropium) in improvement of lung functional test values in patients with asthma and chronic obstructive diseases. These results are in full coherence with the results of the author Mue Mue et al. [25]. In addition to the bronchodilator effect, author Gosens et al suggest that anticholinergic substances, especially those of extended action like tiotropium bromide, might also reduce the constriction of lung functions [26].
Daniel and Ileen et al. [27,28] suggest that alfa-1 adrenergic receptors in the smooth bronchial musculature may be stimulated only with a direct action of catecholamines in circulation, only in physiologic doses because only rarely do sympathetic innervations lie on bronchial tree.

It is found that noradrenaline inhibits relaxing effects of yohimbine in isolated tracheal preparations [29]. Existance of the adrenergic receptors and their role in healthy people and people ill from bronchial asthma and obstructive chronic bronchitis (in vivo) is not yet clarified. Therefore, further research is necessary to clarify this dilemma as far as the role of the alpha adrenergic system in modulating of the tonus of smooth musculature. The role of the alpha adrenergic system may be an important mechanism which causes increased bronchial reactibility.

\section{Conclusion}

Based on gained results, it can be concluded as follows:

- Inhaling of dopamine $(4 \mu \mathrm{g} / \mathrm{kg}$ and $300 \mu \mathrm{g} / \mathrm{kg})$ at diseased with bronchial asthma has caused an increase of the specific resistance (SRaw) of airways $(\mathrm{p}<0.01)$.

- Application of tolazoline $20 \mathrm{mg}$, as aerosol, at diseased with bronchial asthma does not cause decrease of the specific resistance (SRaw) of airways ( $\mathrm{p}>0.1)$.

- Application of hexoprenaline, as aerosol, causes significant decrease of specific resistance (SRaw) of airways ( $\mathrm{p}<0.01)$.

- Atropine, as antagonist of the cholinergic system, applied as aerosol in patients with bronchial asthma also causes significant decrease of specific resistance (SRaw) of airways ( $p>0.1$ ).

This suggests that the application of adrenergic agonists and atangonists in the diseased with bronchial asthma does not change the activity of alpha-1 adrenergic receptors in the airways smooth musculature in the same amount. Same receptor reacts on agonist while it does not react on antagonist adrenergic substances. Therefore, it may be an important mechanism which causes response on diseased 
Citation: Islami H, Krasniqi S, Abdullahu B, Ibrahimi I (2011) Adrenergic Agonist and Antagonist Action in Airways of Patients with Bronchial Asthma. J Pulmonar Respirat Med 1:104. doi:10.4172/2161-105X.1000104

Page 4 of 5

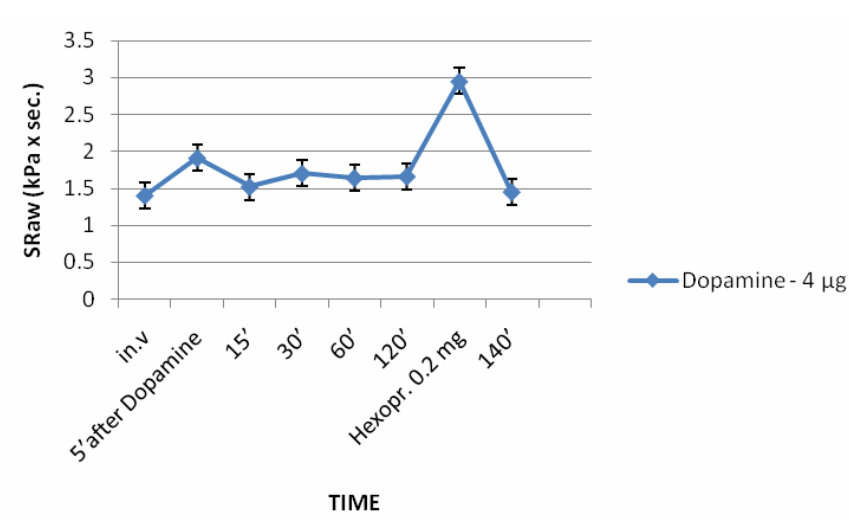

$(n=6 ; X \pm$ SEM $)$

Figure 2: Effect of the dopamine in vivo $(4 \mu \mathrm{g})$ in SRaw on patients with bronchial asthma.

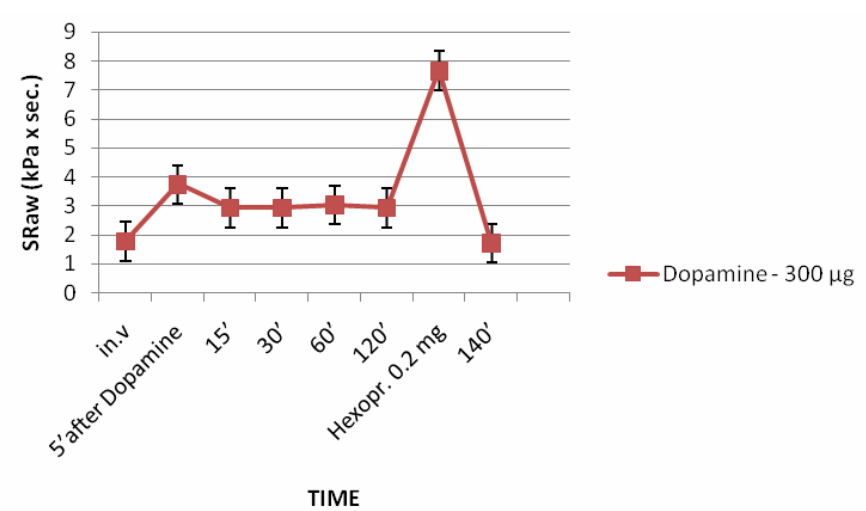

$(n=6 ; X \pm$ SEM)

Figure 3: Effect of the dopamine in vivo $(300 \mu \mathrm{g})$ in SRaw on patients with bronchial asthma.

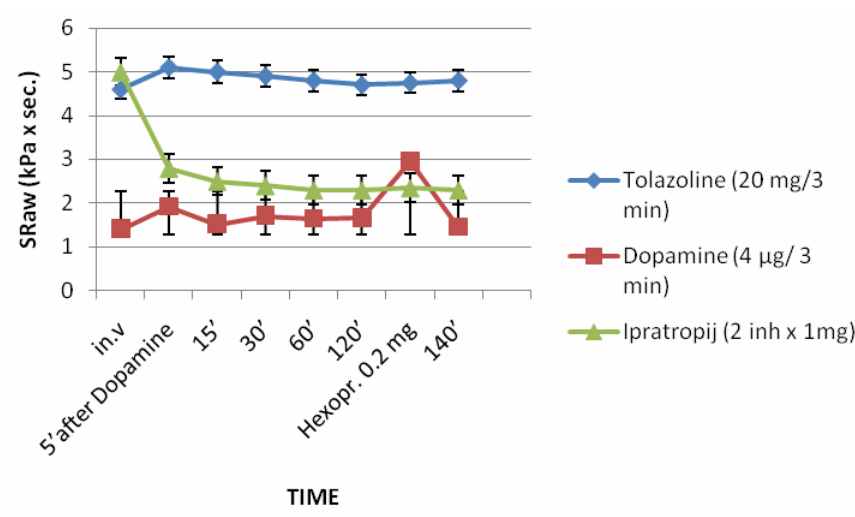

$(n=6 ; X \pm$ SEM)

Figure 4: Effect of the dopamine $(4 \mu \mathrm{g})$, tolazoline and ipratropium in SRaw on patients with bronchial asthma.

of increased bronchial reactibility. There is a possibility that sub-types of alpha- 1 and alpha- 2 adrenergic receptors persist, yet in insufficient amount to react significantly with antagonist alpha-2 adrenergic substances.

\section{References}

1. Pequignot JM, Favier R, Desplanches D, Peyrin L, Flandrois R (1985) Free dopamine in dog plasma: lack of relationship with sympathoadrenal activity. $J$ Appl Physiol 58: 763-769.

2. Scatton B (1982) Further evidence for the involvement of $D_{2}$, but not $D_{1}$ dopamine receptors in dopaminergic control of striatal cholinergic transmission. Life Sci 31: 2883-2890.

3. Bigornia L, Allen CN, Jan CR, Lyon RA, Titeler M, et al. (1990) $D_{2}$ dopaminereceptors modulate calcium channel currents and catecholamine secretion in bovine adrenal chromaffin cells. J Pharmacol Exp Ther 252: 586-592.

4. Rump LC, Schwertfeger E, Schuster MJ, Schaible U, Frankensmidt A, et al. (1993) Dopamine DA2-receptor activation inhibits noradrenaline release in human kidney slices. Kidney Int 43: 197-204.

5. Stoof JC, Kebabian JW (1984) Two Dopamine Receptors: Biochemistry, Physiology and Pharmacology. Life Sci 35: 2281-2296.

6. Racké K, Juergens UR, Matthiesen S (2006) Control by cholinergic mechanisms. Eur J Pharmacol 533: 57-68.

7. Szentivanyi A (1968) The beta adrenergic theory of the atopic abnormality in bronchial asthma. J Allergy 42: 203-232.

8. Gwilt CR, Donnelly LE, Rogers DF (2007) The non-neuronal cholinergic system in the airways: an unappreciated regulatory role in pulmonary inflammation? Pharmacol Ther 115: 208-222.

9. Barnes PJ (1986) Neural control of human airways in health and disease. Am Rev Respir Dis 134: 1289-1314.

10. Gross NJ (1988) Ipratropium bromide. N Engl J Med 319: 486-494.

11. Jooste E, Zhang Y, Emala CW (2007) Neuromuscular blocking agents differential bronchoconstrictive potential in Guinea pig airways. Anesthesiology 106: 763-772.

12. Patel KR, Kerr JW (1973) The airways response to phenylephrine afte blockade of alpha and beta receptors in extrinsic bronchial asthma. Clin Allergy 3: $439-448$.

13. Thomson NC, Daniel EE, Hargreave FE (1982) Role of smooth muscle alpha1 receptors in nonspecific bronchial responsiveness in asthma. Am Rev Respir Dis 126: $521-525$.

14. Simonsson BG, Skoogh BE, Bergh NP, Andersson R, Svedmyr N (1973) In vivo and in vitro effect of bradykinin on bronchial motor tone in normal subjects and patients with airways obstruction. Respiration 30: 378-388

15. Anzueto A, Tashkin D, Menjoge S, Kesten S (2005) One-year analysis of longitudinal changes in spirometry in patients with COPD receiving tiotropium. Pulm Pharmacol Ther 18: 75-81.

16. Black JL, Temple DM, Anderson SD (1978) Long-term trial of an alpha adrenoceptor blocking drug (Indoramin) in asthma. A preliminary report. Scand J Respir Dis 59: 307-312.

17. Krop M, Ozünal ZG, Chai W, de Vries R, Fekkes D, et al. (2010) Mast cell degranulation mediates bronchoconstriction via serotonin and not via renin release. Eur J Pharmacol 640: 185-189.

18. Lux R, Awa W, Walter U (2009) An interdisciplinary analysis of sex and gender in relation to the pathogenesis of bronchial asthma. Respir Med 103: 637-649.

19. Lindgren BR, Ekström T, Andersson RG (1986) The effect of inhaled clonidine in patients with asthma. Am Rev Respir Dis 134: 266-269.

20. Walden SM, Bleecker ER, Chahal K, Britt EJ, Mason P, et al. (1984) Effect of alpha-adrenergic blockade on exercise-induced asthma and conditioned cold air. Am Rev Respir Dis 130: 357-362.

21. Giussani DA, Moore PJ, Bennet L, Spencer JA, Hanson MA (1995) Alpha1and alpha2-adrenoreceptor actions of phentolamine and prazosin on breathing movements in fetal sheep in utero. J Physiol 486: 249-255.

22. Islami H, Krasniqi S, Ahmetaj H, Haliti N, Kurtishi I, et al. (2011) Phentolamine action in permeability of airways at patients with bronchial asthma. Med Arh 65: $4-8$

23. Leff AR, Munoz NM (1981) Evidence for two subtypes of alpha adrenergic receptors in canine airway smooth muscle. J Pharmacol Exp Ther 217: 530 535

24. Andersson RG, Fugner A, Lindgren BR, Muacevic G (1986) Inhibitory effects 
Citation: Islami H, Krasniqi S, Abdullahu B, Ibrahimi I (2011) Adrenergic Agonist and Antagonist Action in Airways of Patients with Bronchial Asthma. J Pulmonar Respirat Med 1:104. doi:10.4172/2161-105X.1000104

of clonidine on broncospasm induced in guinea-pigs by vagal stimulation or antigen challenge. Eur J Pharmacol 123: 181-185.

25. Mue S, Ohmi T, Suzuki S, Tamura G, Hida W, et al. (1983) The effect of adrenergic and cholinergic drugs on methacholine- and histamine-induced bronchoconstriction in monkeys. Tohoku J Exp Med 140: 109-119.

26. Gosens R, Zaaqsma J, Meurs H, Halayko AJ (2006) Muscarinic receptor signaling in the pathophysiology of asthma and COPD. Respir Res 7:73.
27. Daniel EE, Davis C, Jones TR, Kannan MS (1982) Control of human airway smooth muscle: in vitro studies. J Appl Physiol 53: 1080-1087.

28. Gilbert IA, Lenner KA, McFadden ER Jr (1988) Sympathoadrenal response to repetitive exercise in normal and asthmatic subjects. J Appl Physiol 64: 2667 2674

29. Russell JA (1987) Presynaptic alpha-2 receptors inhibit norepinephrine release in tracheal smooth muscle. Respir Physiol 70: 25-35. 